\title{
Turizm Öğrencilerinin Hatay İli Somut Kültürel Miras Değerine Yönelik Algıları: İskenderun Teknik Üniversitesi Örneği
}

\section{Perceptions of Tourism Students on The Value of The Cultural Heritage of Hatay Province: The Case of İskenderun Technical University}

\author{
Mehmet Keskin, a, ${ }^{\text {* }}$ Çağrı Saçl1, ${ }^{\mathrm{b}}$ Dilek Efe ${ }^{\mathrm{c}}$ \\ a İskenderun Teknik Üniversitesi, Turizm İşletmeciliği ve Otelcilik Anabilim Dalı, 31200, Hatay/Türkiye \\ ORCID: 0000-0001-8366-5662 \\ ${ }^{b}$ Dr. Öğr. Üyesi, İskenderun Teknik Üniversitesi, Turizm İșletmeciliği ve Otelcilik Anabilim Dalı, 31200, Hatay/Türkiye \\ ORCID: 0000-0001-7771-8190 \\ c Öğr. Gör., İskenderun Teknik Üniversitesi, Seyahat İşletmeciliği ve Turizm Rehberliği Bölümü, 31200, Hatay/Türkiye \\ ORCID: 0000-000105957-7312
}

\section{MAKALE BİLGISİ \\ Makale Geçmişi: \\ Başvuru tarihi: 04 Şubat 2019 \\ Düzeltme tarihi: 20 Kasım 2019 \\ Kabul tarihi: 06 Aralık 2019}

\section{Anahtar Kelimeler:}

Somut kültürel miras,

Hatay

İskenderun Teknik Üniversitesi

\section{A R T ICLE INFO}

Article history:

Received 04 February 2019

Received in revised form 20 November 2019

Accepted 06 December 2019

\section{Keywords:}

Tangible Cultural Heritage

Hatay

İskenderun Technical University
ÖZ

$\mathrm{Bu}$ araştırma, 2017 yılında İskenderun Teknik Üniversitesi Turizm işletmeciliği ve Otelcilik Yüksekokulu lisans öğrencilerinin Hatay'ın somut kültürel varlıklarına dair algılarının ölçülmesini amaçlamaktadır. Araştırmada, anket tekniği kullanılarak 338 adet anket verisine ulaşılmıştır. Araştırma da öğrencilerin Hatay'ın kültürel varlıklarına verdikleri önem derecesi ve ölçekler arasındaki ilişkiler tespit edilmeye çalışılmıştır. Çalışma sonucunda öğrencilerin çeşitli kısıtlar doğrultusunda kültürel aktivitelere katılım gösteremedikleri ve son sınıfta öğrenim gören öğrencilerin bilgi birikim düzeylerinin ve 4. Sınıftaki öğrencilerin algı düzeylerinin alt sınıflardaki öğrencilere oranla daha yüksek olduğu görülmektedir.

\section{A B S T R ACT}

This research aims to measure the perceptions of Iskenderun Technical University Tourism Management and Hotel Management School undergraduate students regarding the tangible cultural assets of Hatay. In the research, 338 questionnaire data were reached by using questionnaire technique. In the research, the degree of importance given to the cultural assets of Hatay and the relationships between the scales were tried to be determined. As a result of the study, it is seen that the students are not able to participate in cultural activities in line with various constraints, and the knowledge level of students in the last year and the perception levels of the students in the 4th grade are higher than the students in the lower grades.

\section{Giriş}

Hızla gelişen ve değişen turizm pastasından daha fazla pay almak isteyen dünya ülkeleri, turizmin ekonomik anlamda getirilerinden faydalanmak, yaşam standartları ve bölgesel kalkınma anlamında üst seviyeye ulaşmak için turizmin hemen hemen her alanda çeşitlerinden faydalanmayı amaç edinmiş (Golzardi vd., 2012, 863) ve tüketici ihtiyaçları doğrultusunda yeni ürünler geliştirme yoluna gitmişlerdir. Alternatif turizmin ortaya çıkışı da bu doğrultuda gerçekleşmiştir (Kiper, 2006: 1). Alternatif turizm, turizmin yarattığı tüm olumsuz etkileri azaltmak ve değișen turist profilinin ihtiyaçlarını karşılamak için yeni turistik ürünlerin kullanılması ile ortaya çıkmış bir turizm çeşididir (Hacıoğlu ve Avcıkurt, 2008: 8). Dünya turizm örgütü verilerine göre uluslararası çapta seyahat eden turistlerin \% 37'sinin kültürel deneyimleme amacıyla seyahat ettiklerini göstermektedir. Buna istinaden turizm çeşitlerinden biri olan kültür turizmi, turistlerin değişen istek ve ihtiyaçları

* Sorumlu yazar/Corresponding author.

e-posta: mehmet.im@hotmail.com 
ile giderek büyümektedir. Kültür ve kültürel alanlarda gerçekleşen seyahatlerin artışındaki sebep, insanların yeni kültürler tanıma, otantik yerleri ziyaret etme ve gezileri süresince kültürel anlamda keşif yapma isteği içinde olmalarıdır. Buna istinaden kültür turizmi giderek gelişim göstermektedir (Aliağaoğlu, 2004:51; Wang vd., 2006: 49-50). Dünya turizm örgütü verileri uluslararası seyahat eden turistlerin \%37'sinin kültürel ihtiyaçlarını karşılamak adına seyahatlerini gerçekleştirdiklerini ve bu oranın her yıl \% 15 oranında arttığını (Günal vd., 2009; 277) göstermektedir. Bununla birlikte klasik tatil anlayışı veya iş gezisi, akraba, arkadaş ziyareti gibi farklı nedenlerle seyahat eden turistlerin dahi seyahatlerinin belirli bir k1smında kültür turizmi etkinliklerine katıldıkları görülmektedir (Hughes, 2002; 169).

Kültür, toplumların tarihsel gelişme süreçleri içinde ortaya çıkarılan bütün maddi ve manevi değerlerle bunları ortaya çıkarırken nesilden nesile aktarmada kullanılan, insanın sosyal ve fiziksel çevresine olan üstünlüğünü gösteren araçların toplamıdır (TDK, 2018). Kültür, tarihsel gelişme süreci içerisinde birikmekte ve sonraki nesillere aktarılmaktadır. Kültürün yarattığı kültürel miras "Ínsanlık tarihinin başlangıcından bu yana, insanın yaratıcıllı̆g ve toplumlararası etkileşimler sonucunda ortaya çıkan kültürel değerlerin birikimidir” (Küçükaltan vd., 2011: 236). Kültür ve kültürel mirastan doğan kültür turizmi, turistlerin ziyaret ettikleri bölgenin tarihçesi ve değerleri öğrenmesi, tatması ve o ulusa ait değerleri en iyi şekilde sergileyebileceği kavram olarak tanımlanmaktadır (Üsküdar vd., 2014: 69; Usta, 2012: 163). Somut kültürel miras ise toplumların geçmişten günümüze yaşadıkları dönemin ve bölgenin koşullarına göre bulundukları bölgelerde toplumun kültürel maddi ve manevi değerleri doğrultusunda yapmış oldukları yapıtlar ve bu yapıtların günümüze kadar ulaşmış hali olarak tanımlanmaktadır (Demirbulat vd, 2015: 64).

Bireylerdeki tarih ve kültürel mirasların değerini arttıran bir anımsatıcı olarak somut kültürel miras turizmini bölgede yaşayan insanların yaşam tarzlarını korumayı ve insanların hayat standartlarını arttırmayı hedefleyen bir turizm çeşidi olarak ifade etmek mümkündür (Shackley, 1997:245). Kültür turizmi potansiyeli olan kültürel miraslar yeterli koruma işlemleri ve tanıtımları yapılmadığında zaman içerisinde yok olmaya yüz tutmaktadır (Selman, Dikmenli ve Çetin, 2014: 173). Bu değerlerin bir sonraki nesillere aktarılması için bölgenin korunması, geliştirilmesi ve bölge içinde bulunan değerleri turizm potansiyeli açısından kullanılırken kültürel miraslara gerekli önemin verilmesi gerekmektedir (Ablak vd., 2014: 173).

Dünya tarihinde Anadolu, birçok medeniyetin (Hititler, Likyalılar, Frigyalılar, Selçuklular, Osmanlılar vb.) varoluşuna, gelişimine ve çöküşüne şahitlik etmiştir. Bu medeniyetler Türkiye Cumhuriyeti'ne gelinceye kadar çeşitli tarihi değer ve yapıtları arkalarında bırakarak, Türkiye'yi kültürel zenginlikleri bakımından eşsiz bir konuma getirmişlerdir (Doğaner, 2001). Tarih, resim, mimari yapı ve el sanatları gibi kültürel değerler Anadolu'yu zengin kılan diğer önemli unsurlardandır. Tarihi yapılar, kültürel alanlar, arkeolojik yerler ve anıtsal yapılar, müzeler, kütüphaneler vb. alanlar, kültür turizmine zenginlik katmaktadır (Üsküdar, Çakır ve Temizkan, 2014: 70).

Yapılan bu çalışmada zengin kültürel mirası ile birçok uygarlığa, üç büyük din ve çok sayıda kültüre binlerce yıl huzur içinde ev sahipliği yapmış ve yapmakta olan, sekiz bin yıllık geçmişi ile ilk küresel şehir olma özelliği ( Gökçe vd., 2017; 1475) taşıyan; barışın, kardeşliğin ve hoşgörünün sembolü (Tosun ve Bilim, 2004: 128) Hatay'ın sahip olduğu kültür varlıklarına ilişkin algı düzeylerinin belirlenmesi, bu bağlamda söz konusu mirasların önemine dikkat çekmek amaçlanmıştır.

Çalışmada İskenderun Teknik Üniversitesi’nde öğrenim gören turizm öğrencilerinin, Hatay'da bulunan somut kültürel varlıklara ilişkin algı düzeylerinin belirlenmesi amaçlanmaktadır.

\section{Kavramsal Çerçeve}

\subsection{Kültürel Miras ve Somut Kültürel Miras}

Kültürel miras geçmişte yaşamış topluluklar tarafından oluşturulan gelenekler ve bu geleneklerin oluşturulma biçimleri, topluma ait sanatsal eserler, toplumların günlük yaşamlarındaki uygulamaları, törenler, adetler, festivaller ve çeşitli deneyimler sonucu ortaya çıkan bilgilerin gelecek nesillere aktarımı şeklinde ifade edilmektedir (Vecco, 2010;622). Başka bir ifadeyle kültürel miras, geçmişten günümüze miras bırakılmak istenen, maddi, manevi ve fiziksel varlığı olan ve dönemin insanları tarafindan yapılan eserler ile bir ulusa ait birikimlerin toplamını oluşturmaktadır (Can, 2009:3). Avrupa Konseyi ise kültürel mirası geçmişten kalan, insanların sürekli değişen değer, yargı, inanç, tutum, gelenek ve bilgi birikimlerinin bir ifadesi olarak tanımlamaktadır (Counsil of Europe, 2018). Somut kültürel miras ise; ulusların yaşadıkları dönemin dini ve coğrafik koşullarına bakılarak yapmış oldukları yapılardan meydana gelmektedir. Somut kültürel miraslar genel olarak mimari, arkeolojik ve bilimsel eserlerden oluşmaktadır (Can, 2009:3).

Her milletin kendine özgü kültürü ve kültürel varlıkları vardır. Ancak bu varlıklar koruma altına alındığında ve iyi değerlendirildiğinde bir sonraki nesillere aktarılabilecek ve sürdürülebilir özellikte olabilecektir. Tarihi kültürel mirasların korunmasında, düzenlenmesinde müzeler ve sit alanları büyük ölçüde önem kazanmıştır (Meydan Uygur ve Baykan, 2007: 41). Kültürel mirasların koruma ve restorasyon gibi işleri, içinde olduğu bölgenin kültürel anlamda kimliğinin zarar görmemesi açısından önemli bir durum olmaktadır. Söz konusu değerlerin korunması adına bakanlık, belediyeler, STK'lar ve bazı eğitim kurumları bu anlamda bir takım çalışmalar yapmaktadırlar. Yasalar tarafından saptanan görevler ile kültürel mirasın zarar görmemesi adına alınan kararlarda mirasın tespit edilmesi, gerekli restorasyon işlerinin yapılması gibi kararlar Koruma Bölge Kurullarına verilmiştir. $\mathrm{Bu}$ kurullar arasındaki koordinasyon ve kültürel yapıya sahip restorasyon gerektiren yapılardaki durumlarla alakalı izlenecek yolu belirlemek ise Kültür ve Tabiat Varlıklarını Koruma Yüksek Kurulu'na bırakılmıştır. Bu kurum çalışanlarının, sanat tarihi, arkeoloji, mimari vb. alanlarda uzman olmaları gerekmektedir (Kozak ve diğerleri, 2012, 81).

Ülkemizin önem arz eden kültürel miraslarını korumak ve gözetmek, toplumsal anlamda birliğin artmasını, kültürel anlamda benliğin korunmasını ve geleceğe yön verme bakımından kararların etkisini olumlu yönde değiştirecektir. Bununla birlikte dünyada kültürel benliğe/kimliğe hakim olmak, uluslararası kapsamda etkileşimin daha güçlü olacağı ve ülkeler arası rekabet ortamında yer almayı sağlar. Keşfetme, bilgi sahibi olma ve kültürel anlamda gelişim 
kaydetmeyi amaç edinmiş bireylerin kendi kültürlerine sahip çıkma istekleri insanlık namına önemli bir görev olmaktadır (Külcü, 2015, 30).

Dünya Kültürel ve Doğal Mirasının Korunmasına Dair Sözleşmesi Birleşmiş Milletler Eğitim, Bilim ve Kültür Örgütü'nün Genel Konferansı'nda 16 Kasım 1972'de kabul edilmiş (Akipek, 2001; 13), 14 Nisan 1982 yılında Türkiye'nin bu sözleşmeye katılması uygun bulunmuş; 23 Mayıs 1982 yılında Bakanlar kurulu kararıyla onaylanıp, 14 Şubat 1983 yılında resmi gazetede yayınlanarak bu sözleşmeye taraf olunmuştur (Kültür Varlıkları, 2018).

UNESCO'nun Dünya Kültürel ve Doğal Mirasın Korunması Sözleşmesi (16 Kasım 1972)'ne göre, kültürel mirası oluşturan unsurlar arasinda anitlar, sitler ve yapilar bulunmaktadır (teftis.kulturturizm.gov.tr, 2017).

\subsection{Hatay'a Ait Genel Bilgiler}

Kültür turizmi potansiyeli açısından Türkiye'nin doğal, tarihi ve kültürel mirası özelliğinde olan değerler, taşınır taşınmaz varlıklar, doğal ve kültürel miraslar, tarihte bilim, kültür vb. güzel sanatlarla ilgili, yer altı, yerüstü veya su altındaki varlıklar olarak tanımlanmaktadır (Doğaner, 2001: 135). Hatay, tarihin en eski dönemlerinden bu zamana kadar Anadolu'nun en köklü yerleşim merkezlerinden biri olmuştur. Bölgenin tarihi M.Ö. 100.000’le başlayan Orta Paleolitik döneme kadar dayanmaktadır. Bölgenin tarihi, insanların yaşamını kolaylaştıran verimli toprakların yanında ılıman iklim koşullarının olması nedeniyle her dönemde göç almıştır. Bölgenin her dönemde göç almasının bir başka sebebi ise, Anadolu'yu, Suriye ve Filistin'e bağlayan yolların ortak noktasında bulunmasıdır. Ayrıca Hatay ili Mezopotamya'dan Akdeniz'e gitmek için en uygun limanlara sahip olması nedeniyle de stratejik öneme sahiptir. Bölgeye Hatay adı 1936 yılında Mustafa Kemal Atatürk tarafından verilmiştir (http://www.hatay.gov.tr/tarih, 2017).

\subsection{Hatay’da Öne Çıkan Somut Kültürel Miraslar}

Hatay ilinde öne çıkan kültürel miraslar arasında; Habib-i Neccar Camii, Saint Pieere Kilisesi, Sokullu Mehmet Paşa Külliyesi ve Payas Kalesi, Hatay Arkeoloji Müzesi, Kurtuluş Caddesi, Havra, Katolik Kilisesi, Ortodoks Kilisesi, Harbiye, Daphne, Eski Antakya Evleri, Haron, Cehennem Kayıkçısı, Antakya Uzun Çarşı, Antakya Surları, Samandağ (Çevlik), Selecia Pieria Antik Kenti, Titus Tüneli ve Beşikli Mağara (Kaya Mezarları), St. Simeon Manastırı, Hıdırbey Köyü ve Musa Ağac1, Dor Mabedi, Yenişehir Gölü (İmma Antik Kenti), Vakıflı Köyü, Ermeni Kilisesi, Koz Kalesi, Darb-1 Sak Kalesi (Beyazid-i Bestami Makamı), İsos Antik Kenti Erzin, İskenderun Deniz Müzesi, Kanuni Sultan Süleyman Kervansarayı, Kinet Höyük, Erzin Başlamış Kaplıcaları ve Batıayaz Yaylası yer almaktadır (www.hatay.gov.tr, 2017).

\section{Literatür Taraması}

Çağdaş yaşamın vazgeçilmez unsuru olması ile birlikte turizm sektörünün ülke kalkınması açısından önemli bir payının olduğu bilinmektedir. $\mathrm{Bu}$ nedenle yüksek gelir sağlaması bakımından gerekli planlamaların yapılması gerekmektedir. Turizm hareketlerinin yoğun olarak gerçekleştiği bölgelerde kazancın daha fazla olması için turizm çeşitliliğin arttırılması gerekmektedir. Bu gereklilik itibari ile söz konusu bölgelerde bulunan kültürel miras, bu amaç doğrultusunda bölgeye fayda sağlayacaktır (Kurgun ve Yumuk, 2013, 27). Kültür varlıkları, bir toplumun yaşamı boyunca deneyimlediği ve içinde bulunduğu topluma ait onu diğer topluluklardan ayıran önemli özellikleri bünyesinde bulundurması ile eşsiz eserlerdir (Külcü, 2015, 28). Kültürel bir değerin miras değeri kazanabilmesi ancak bu değerin benimsenmesi, tanıtılması ve toplumun bir parçası haline gelmesi ile mümkün olmaktadır (Karaca Yılmaz, Akkuş, Şahbudak ve Işkın, 2017, 87). Söz konusu kültürel değerin tespit edilmesi, miras değeri kazanmasının ardından yapısında herhangi bir bozulmaya sebebiyet vermeksizin onarılma ve korunma işlemlerinin doğru bir şekilde yapılması ve gelecek nesillere aktarılmasında (Kozak, Tören ve Demiral, 2012,70) ve kültürel miras kapsamında sürdürülebilirliğini ve devamlılığının sağlanması çağdaş yaşamın vazgeçilmez bir unsuru olmaktadır (Giritlioğlu, Armutçu, Düzgün, 2016, 127).

Yapılan alan yazın incelemesinde somut kültürel mirasların, arkeolojik ve mimari yapılar olmakla beraber kendi içerisinde taşınabilir ve taşınamayan somut kültürel miraslar olarak iki temel başlıkta ikiye ayrıldıklarını göstermektedir (Ahunbay, 2007,22; Pulhan vd., 2012,62 ). Uygur ve Baykan (2007) çalışmalarında kültür ve kültür turizmi kavramları ve kaynakları üzerinde durmuş, kültür turisti tiplerinin anlaşılmasını sağlayarak, turizmin kültürel varlıklar üzerindeki olumlu ve olumsuz etkilerini araştırmışlardır. Yine benzer bir şekilde somut kültürel miras kavramı ve tanımını irdeleyen, kültürel miras kavramına ilişkin metaforların ölçüldüğü çalışmalara rastlanmaktadır ( Vecco, 2010; 321; Selanik Ay ve Kurtdere Fidan, 2013; 1135; Alzahrani, 2013; 9;). Bununla birlikte somut kültürel miras varlıklarının korunmasına dair yapılan çalışmalarda bu değerlerin bir sonraki nesillere aktarılması için bölgenin gerekli politika ve planlamalarla korunması, geliştirilmesi (Unesco, 1972; Teo ve Huang, 1995;589; Tankut, 2005; 7; Özdemir, 2011; 129; Shankar ve Swamy, 2013; 698; 129; Ablak vd., 2014: 173;) ve kültürel miras kapsamında sürdürülebilirliğini ve devamlılığının (Giritlioğlu, Armutçu, Düzgün, 2016, 127) sağlanmasının önemi vurgulanmaktadır. Öğrencilerin somut kültürel mirasın algısının ölçülmesine yönelik yapılan çalışmalarda kültür turizmi faaliyetlerinin koruma-kullanma dengesi kapsamında arttırılması, öğrencilerin ve halkın kültür mirasları ile ilgili bilincinin arttırılması, maliyet ve ulaşılabilirlik konularında düzenlemelerin getirilmesi gerekliliği vurgulanmaktadır ( Karaca Yılmaz vd., 2017; 97; Demirbulat vd., 2015; 83; Kutlu, 2009; 17). Kültürel Miras yönetimi ile ilgili kültür politikalarının ve kültürel mirası korumaya ilişkin alınması gereken önlemlerin önemi vurgulanmaktadır (Dağıstan Özdemir; 2005; 20; McKercher v.d., 2005; Aas, v.d., 2005; Taylor, 2007; Özdemir, 2011; 73).

\section{Araştırmanın Yöntemi}

$\mathrm{Bu}$ araştırma açıklayıcı bir araştırma olup 2017 yılı 5-8 tarihinde İskenderun Teknik Üniversitesi Turizm İşletmeciliği ve Otelcilik Yüksekokulunda öğrenim gören turizm öğrencilerinin Hatay'ın somut kültürel varlıklarına dair algılarının ölçülmesini amaçlamaktadır. Araştırmada ölçek maddelerinin belirlenmesinde Demirbulat ve diğerleri (2015) tarafından gerçekleştirilen ölçekten yararlanılmıştır. Veriler birebir anket tekniği kullanılarak elde edilmiştir. Anketin birinci bölümünde, katılımcıların demografik bilgileri sorgulanmıştır. İkinci bölümde, öğrencilerin Hatay’da yer alan kültürel varlıklara dair algılarının ölçülerek verdikleri önem derecesi belirlenmeye çalışılmıştır. Daha sonra Hatay şehir merkezini ziyaret etme nedenleri ve tarihi bir bina 
gördüklerinde hissettikleri duyguyu anlamaya yönelik sorular yöneltilmiştir. Son olarak, öğrencilerin somut kültürel varlıklara ilişkin tutum algılarını belirlemeye yönelik 21 önermeden oluşan; 1 Kesinlikle katılmıyorum, 2 Katılmiyorum, 3 Ne katılmıyorum ne katıliyorum, 4 Katılıyorum ve 5 Kesinlikle katılıyorum ifadelerinden oluşan 5'li likert şeklinde üçüncü bölüm sunulmuştur. Araştırmada veriler kolayda örnekleme yöntemi ile toplanılmıştır. Araştırma evrenini İskenderun Teknik Üniversitesi öğrencilerinin oluşturduğu kabul edilmiştir. Örneklem sayısı hesaplanırken evren büyüklüğü 1300 kişiyi temsil eden bir çalışmada en az 297 adet anket sayısının örneklemi temsil edebileceği (Altunışık vd., 2010; 137) yargısına başvurulmuştur. Hatay'ın İskenderun ilçesinde bulunan İskenderun Teknik Üniversitesi (ISSTE), Türkiye Büyük Millet Meclisi'nin 31.3.2015 tarihinde çıkardığg 6640 sayılı bir yasayla İskenderun ilçesinde kurulmuş teknik üniversitedir. İskenderun Teknik Üniversitesini oluşturan fakültelerin ve yüksekokulların çoğu Mustafa Kemal Üniversitesi'nden ayrılarak yeni üniversiteye bağlanmıştır. Bu yüksekokullardan biri olan Turizm işletmeciliği ve Otelcilik Yüksekokulu 2017/2018 akademik yılında, Turizm ve Otel İşletmeciliği ve Seyahat İşletmeciliği programları olmak üzere toplam 2 program ve 1248 öğrenci ile eğitime devam etmektedir (www.iste.edu.tr, 2017). Bu noktada, örneklem sayıs1 belirlenirken İskenderun Teknik Üniversitesi'nde turizm eğitimi alan lisans öğrencilerinin evreni temsil ettiği kabul edilmiş turizm eğitimi alan 338 öğrenciden elde edilen anket formu ile analizler gerçekleştirilmiştir.

Yapılan anketler sonucu elde edilen veriler SPSS (IBM Statistical Package for Social Sciences, Version 22) paket programı kullanılarak analiz edilmiştir. Katılımcıların demografik değişenlerinin yüzdelerini ortaya koymak için frekans analizi uygulanmış, sonrasında Hatay'ın somut kültürel varlıklarına olan algılarını belirlemek amacıyla oluşturulan ifadelere verdikleri yanıtlar, aritmetik ortalama ve standart sapma değerleri alınarak analiz edilmiştir. Bununla beraber verilere güvenilirlik analzi ve normallik testi uygulanmıştır. Normallik testi sonucunda verilerin normal dağılım göstermediği görülmüştür. Örneklem sayısı hesaplanırken; parametrik testlere ilişkin koşulların gerçekleşmediği durumlarda, parametrik testlere ilişkin örneklem koşulları ile parametrik olmayan testlere ilişkin örneklem koşullarının aynı kabul edildiği (Ural ve Kılıç, 2013; 253) yargısına başvurulmuş ve ölçeklerin analizinde Mann Whitney- U testi ile Kruskal Wallis H testleri uygulanarak ölçekler arasındaki ilişkiler tespit edilmeye çalışılmıştır.

\section{Bulgular}

Ankete katılan öğrencilerin cinsiyetlerini, yaşlarını, sınıf düzeylerini, aylık gelir düzeylerini, ikamet yerlerini, ailelerinin ikamet yerlerini, memleket yerlerini ve öğrenim gördükleri bölümleri kapsayan demografik özellikleri Tablo 1 'de sunulmuştur.

Tablo 1. Araştırmaya Katılan Öğrencilerin Demografik Özelliklerine Yönelik Bulgular

\begin{tabular}{|c|c|c|}
\hline Cinsiyet & $\mathbf{N}$ & $\%$ \\
\hline Kadın & 113 & 33,4 \\
\hline Erkek & 225 & 66,6 \\
\hline Yaş & $\mathbf{N}$ & $\%$ \\
\hline $16-18$ yaş & 12 & 3,6 \\
\hline 19-21 yaş & 154 & 45,6 \\
\hline $22-24$ yaş & 129 & 38,2 \\
\hline 25 yaş ve üzeri & 43 & 12,7 \\
\hline Sinif & $\mathbf{N}$ & $\%$ \\
\hline 1.Sinif & 60 & 17,8 \\
\hline 2.Sinif & 114 & 33,7 \\
\hline 3.Sinif & 43 & 12,7 \\
\hline 4.Sinif & 121 & 35,8 \\
\hline Gelir Düzeyi & $\mathbf{N}$ & $\%$ \\
\hline 250 TL ve alt 1 & 40 & 11,8 \\
\hline $251-500 \mathrm{TL}$ & 110 & 32,5 \\
\hline $501-750 \mathrm{TL}$ & 71 & 21,0 \\
\hline $751-1000 \mathrm{TL}$ & 62 & 18,3 \\
\hline 1001 TL ve üzeri & 55 & 16,3 \\
\hline İkamet Yeri & $\mathbf{N}$ & $\%$ \\
\hline Aile yanı & 55 & 16,3 \\
\hline Öğrenci evi & 160 & 47,3 \\
\hline Devlet yurdu & 69 & 20,4 \\
\hline Özel yurt & 54 & 16,0 \\
\hline Öğrenim Görülen Bölüm & $\mathbf{N}$ & $\%$ \\
\hline Turizm ve Otel İşletmeciliği & 240 & 71,0 \\
\hline Seyahat İşletmeciliği & 98 & 29,0 \\
\hline Ailenin İkamet Yeri & $\mathbf{N}$ & $\%$ \\
\hline İl & 148 & 43,8 \\
\hline İlçe & 137 & 40,5 \\
\hline Köy & 53 & 15,7 \\
\hline Memleket Yeri & $\mathbf{N}$ & $\%$ \\
\hline Hatay & 95 & 28,1 \\
\hline Hatay D1ş1 & 243 & 71,9 \\
\hline
\end{tabular}

Araştırmaya katılan öğrencilerin demografik verileri incelendiğinde, \%66,6'sını erkekler, \% 45,6'sını 19-21 yaş grubu, \%35,8'ini 4. Sınıf öğrencileri, \%32,5'ini 251-500 TL aylık gelire sahip olan öğrenciler, \% 47,3'ünü öğrenci evinde ikamet eden katılımcılar, \%71,0'ını turizm ve otel işletmeciliği bölümünde öğrenim gören öğrencilerin, $\% 43,8$ 'inin ailelerinin illerde ikamet ettiği ve \%71,9'unun Hatay dışında ikamet eden öğrencilerden oluştuğu görülmektedir. 
Tablo 2. Araştırmaya Katılan Öğrencilerin Demografik Özelliklerine Yönelik Diğer Bulgular

\begin{tabular}{|c|c|c|}
\hline Hatay Şehir Merkezini Ziyaret Etme Nedenleri & $\mathbf{N}$ & $(\%)$ \\
\hline Kültür-Tarih-Sanat & 145 & 42,9 \\
\hline Mimari & 58 & 17,2 \\
\hline Doğal Güzellik & 86 & 25,4 \\
\hline Sağlık & 21 & 6,2 \\
\hline Din & 43 & 12,7 \\
\hline Kongre, seminer, panel ve vb. etkinlikler & 43 & 12,7 \\
\hline Eğitim & 146 & 43,2 \\
\hline Evet & 53 & 15,7 \\
\hline Fuar-Festival & 35 & 10,4 \\
\hline Eğlence & 77 & 22,8 \\
\hline Alışveriş-Moda & 49 & 14,5 \\
\hline $\begin{array}{l}\text { Hatay'da Gezerken Tarihi Bir Bina } \\
\text { Gördügünüzde Ne Hissediyorsunuz? }\end{array}$ & $\mathbf{N}$ & $(\%)$ \\
\hline Heyecan & 38 & 11,2 \\
\hline Merak & 177 & 52,4 \\
\hline Şaşkınlık & 38 & 11,2 \\
\hline Geçmişteymiş gibi & 85 & 25,1 \\
\hline
\end{tabular}

Tablo 2'de görüldüğü üzere araştırmaya katılan öğrencilerin \%43,2'sinin eğitim amaçlı Hatay şehir merkezini ziyaret ettikleri görülmektedir. Bununla birlikte Hatay'da gezerken tarihi bir bina gördüğünüzde ne hissediyorsunuz sorusuna \%52,4’ünün merak yanıtını verdiği görülmektedir.

Tablo 3. Araştırmaya Katılan Öğrencilerin Hatay İlini Simgeleyen Kültürel Varlıklara Verdikleri Önem Derecesine Göre Siralanması

\begin{tabular}{lccc}
\hline $\begin{array}{l}\text { Hatay İlini Simgeleyen Kültürel } \\
\text { Varlıklar }\end{array}$ & N & $\mathbf{( \% )}$ & $\begin{array}{c}\text { Standart } \\
\text { Sapma }\end{array}$ \\
\hline 1. Hatay Arkeoloji Müzesi & 338 & 4,23 &, 940 \\
\hline 2. Habib-İ Neccar Camii & 338 & 4,17 & 1,019 \\
\hline 3. St. Pieere Kilisesi & 338 & 4,14 & 1,043 \\
\hline $\begin{array}{l}\text { 4. Samandağ (Çevlik)- Selecia } \\
\text { Pieria Antik Kenti }\end{array}$ & 338 & 4,13 &, 975 \\
\hline $\begin{array}{l}\text { 5. Sokullu Mehmet Paşa } \\
\text { Külliyesi, Payas Kalesi }\end{array}$ & 338 & 4,09 &, 932 \\
\hline $\begin{array}{l}\text { 6. Titus Tüneli, Beşikli Mağara } \\
\text { (Kaya Mezarları) }\end{array}$ & 338 & 4,07 &, 992 \\
\hline 7. Harbiye - Daphne & & & \\
\hline 8. Eski Antakya Evleri & 338 & 4,03 &, 916 \\
\hline 9. Antakya Surları & 338 & 3,99 &, 980 \\
\hline 10. Hidırbey Köyü, Musa Ağacı & 338 & 3,96 &, 990 \\
\hline 11. St. Simeon Manastırı & 338 & 3,91 &, 990 \\
\hline
\end{tabular}

Tablo 3'te araştırmaya katılan öğrencilerin Hatay ilini simgeleyen kültürel varlıklara verdikleri önem derecesine göre sıralanması görülmektedir. $\mathrm{Bu}$ sonuçlara göre öğrencilerin \%4,23'ü Hatay'ı simgeleyen en önemli kültür varlığının Hatay Arkeoloji Müzesi olduğunu belirtmişlerdir.

\subsection{Güvenilirlik Analizi ve Normallik Testi}

Cronbach Alfa katsayısı, ölçeğin genel güvenilirliğini test etmek için kullanılmaktadır. Cronbach Alpha katsayısı 0 ile 1 arasında değişim göstermektedir. Çalışmada verilerin analizi sonucu Cronbach Alpha katsayısı 0,69 olarak hesaplanmış ve bu değer $0,60 \leq \alpha \leq 0,70$ arasında değer aldığından ölçeğin yeterli güvenilirlik düzeyine sahip olduğu söylenmektedir (Özdamar, 2011; 605). Yapılan analiz çalışmasında ölçeklerin normal dağılmadıkları görülmektedir. Bu noktada örneklem sayısı hesaplanırken; parametrik testlere ilişkin örneklem ile parametrik olmayan testlere ilişkin örneklem koşulları aynı kabul edilmekte ve verilerin normal dağılım göstermediği koşullarda parametrik olmayan testlere başvurulmaktadır (Ural ve Kılıç, 2013; 253). Dolayısıyla çalıșma analizlerinde parametrik olmayan Mann-Whitney U ve Kruskal-Wallis H testleri uygulanmıştır.

Tablo 4. Öğrencilerin Cinsiyetlerine Göre Somut Kültürel Varlıklarına İlişskin Tutum Algılarını Oluşturan Faktörlere Verdikleri Önem Düzeyleri

\begin{tabular}{|c|c|c|c|c|c|}
\hline $\begin{array}{c}\text { Somut Kültürel } \\
\text { Varlıklara İlişkin } \\
\text { Tutum Algılarını } \\
\text { Oluşturan } \\
\text { Faktörler }\end{array}$ & Cinsiyet & $\mathbf{N}$ & $\begin{array}{c}\text { Ortalama } \\
\text { Sirası }\end{array}$ & $\begin{array}{l}\text { Mann- } \\
\text { Whitney } \\
\text { U }\end{array}$ & $\mathbf{P}$ \\
\hline \multirow{2}{*}{$\begin{array}{l}\text { Hatay’ın Somut } \\
\text { Kültürel } \\
\text { Varlıklarına İlişkin } \\
\text { Tutum Algıları }\end{array}$} & Erkek & 225 & 168,36 & \multirow[t]{2}{*}{12,457} & \multirow[t]{2}{*}{,762 } \\
\hline & Kadın & 113 & 171,176 & & \\
\hline \multirow{2}{*}{$\begin{array}{l}\text { Somut Kültürel } \\
\text { Varlıklara İlişkin } \\
\text { Genel Tutum } \\
\text { Algıları }\end{array}$} & Erkek & 225 & 170,94 & \multirow[t]{2}{*}{13,037} & \multirow[t]{2}{*}{,702 } \\
\hline & Kadın & 113 & 166,63 & & \\
\hline
\end{tabular}

Tablo 4'te görüldüğü üzere; katılımcıların Hatay'ın somut kültürel varlıklarına ilişkin tutum algıları anlamlılık düzeyi 0,762, katılımcıların somut kültürel varlıklara ilişkin genel tutum algıları anlamlılık düzeyi 0,702 olarak hesaplanmış ve bu değerler 0,05 'ten büyük olduğundan katılımcıların somut kültürel varlıklara ilişkin tutum algılarını oluşturan faktörler ile cinsiyet değişkeni arasında istatistiki anlamda anlamlı bir farklılık görülmemektedir.

Tablo 5. Öğrencilerin Hatay'da İkamet Edip Etmediklerine Göre Somut Kültürel Varlıklarına İlişkin Tutum Algılarını Oluşturan Faktörlere Verdikleri Önem Düzeyleri

\begin{tabular}{|c|c|c|c|c|c|}
\hline $\begin{array}{c}\text { Somut } \\
\text { Kültürel } \\
\text { Varlıklara } \\
\text { İlişkin } \\
\text { Tutum } \\
\text { Algılarını } \\
\text { Oluşturan } \\
\text { Faktörler } \\
\end{array}$ & $\begin{array}{c}\text { Memleket } \\
\text { Yeri }\end{array}$ & $\mathbf{N}$ & $\begin{array}{c}\text { Ortalama } \\
\text { Sirası }\end{array}$ & $\begin{array}{c}\text { Mann- } \\
\text { Whitney } \\
\text { U }\end{array}$ & p \\
\hline \multirow{2}{*}{$\begin{array}{l}\text { Hatay’ın } \\
\text { Somut } \\
\text { Kültürel } \\
\text { Varlıklarına } \\
\text { İlişkin Tutum } \\
\text { Algıları } \\
\end{array}$} & Hatay & 95 & 205,42 & \multirow[b]{2}{*}{8,130} & \multirow[b]{2}{*}{,000* } \\
\hline & $\begin{array}{l}\text { Hatay } \\
\text { D1ş1 }\end{array}$ & 243 & 155,46 & & \\
\hline \multirow{2}{*}{$\begin{array}{l}\text { Somut } \\
\text { Kültürel } \\
\text { Varlıklara } \\
\text { İlişkin Genel } \\
\text { Tutum } \\
\text { Algıları }\end{array}$} & Hatay & 95 & 177,37 & \multirow[b]{2}{*}{10,795} & \multirow[b]{2}{*}{, 354} \\
\hline & $\begin{array}{l}\text { Hatay } \\
\text { D1ş1 }\end{array}$ & 243 & 166,42 & & \\
\hline
\end{tabular}

Tablo 5'te görüldüğü üzere; katılımcıların Hatay'ın somut kültürel varlıklarına ilişkin tutum algıları anlamlılık düzeyi 0,000, olarak hesaplanmış ve bu değer 0,05'ten küçük olduğundan katılımcıların Hatay'ın somut kültürel varlıklarına ilişkin tutum algıları ile memleket yeri değişkeni arasında istatistiki anlamda anlamlı bir farklılık olduğu görülmektedir. Hatay'lı katılımcıların algı düzeylerinin Hatay'lı olmayan katılımcılara oranla daha yüksek olduğu görülmektedir. Katılımcıların somut kültürel varlıklara ilişkin genel tutum algıları anlamlılık düzeyi 0,354 olarak hesaplanmış ve bu değerler 0,05 'ten büyük olduğundan katılımcıların somut kültürel varlıklara ilișkin tutum algılarını oluşturan faktörler 
ile memleket yeri değişkeni arasında istatistiki anlamda anlamlı bir farklılık görülmemektedir.

Tablo 6. Öğrencilerin Öğrenim Gördükleri Bölüme Göre Somut Kültürel Varlıklarına İlişkin Tutum Algılarını Oluşturan Faktörlere Verdikleri Önem Düzeyleri

\begin{tabular}{|c|c|c|c|c|c|}
\hline $\begin{array}{c}\text { Somut } \\
\text { Kültürel } \\
\text { Varlıklara } \\
\text { İlişkin } \\
\text { Tutum } \\
\text { Algılarını } \\
\text { Oluşturan } \\
\text { Faktörler }\end{array}$ & $\begin{array}{c}\text { Öğrenim } \\
\text { Gördükleri } \\
\text { Bölüm }\end{array}$ & $\mathbf{N}$ & Ort. & $\begin{array}{c}\text { Mann- } \\
\text { Whitney } \\
\text { U }\end{array}$ & p \\
\hline \multirow{2}{*}{$\begin{array}{l}\text { Hatay’ın } \\
\text { Somut } \\
\text { Kültürel } \\
\text { Varlıklarına } \\
\text { İlişkin Tutum } \\
\text { Algıları }\end{array}$} & $\begin{array}{c}\text { Turizm ve } \\
\text { Otel } \\
\text { İşletmeciliği }\end{array}$ & 98 & 163,33 & \multirow[t]{2}{*}{11,155} & \multirow[t]{2}{*}{,457 } \\
\hline & $\begin{array}{c}\text { Seyahat } \\
\text { İşletmeciliği }\end{array}$ & 240 & 172,02 & & \\
\hline \multirow{2}{*}{$\begin{array}{l}\text { Somut } \\
\text { Kültürel } \\
\text { Varlıklara } \\
\text { İlişkin Genel } \\
\text { Tutum } \\
\text { Algıları }\end{array}$} & $\begin{array}{l}\text { Turizm ve } \\
\text { Otel } \\
\text { İşletmeciliği }\end{array}$ & 98 & 175,92 & \multirow[t]{2}{*}{12,389} & \multirow[t]{2}{*}{,440 } \\
\hline & $\begin{array}{c}\text { Seyahat } \\
\text { İşletmeciliği }\end{array}$ & 240 & 166,88 & & \\
\hline
\end{tabular}

Tablo 6'da görüldüğü üzere; katılımcıların Hatay'ın somut kültürel varlıklarına ilişkin tutum algıları anlamlılık düzeyi 0,457, katılımcıların somut kültürel varlıklara ilişkin genel tutum algıları anlamlılık düzeyi 0,440 olarak hesaplanmış ve bu değerler 0,05 'ten büyük olduğundan katılımciların somut kültürel varlıklara ilişkin tutum algılarını oluşturan faktörler ile öğrenim gördükleri bölüm değişkeni arasında istatistiki anlamda anlamlı bir farklılık görülmemektedir.

Tablo 7. Öğrencilerin Yaşa Göre Somut Kültürel Varlıklarına İlişkin Tutum Algılarını Oluşturan Faktörlere Verdikleri Önem Düzeyleri

\begin{tabular}{|c|c|c|c|c|c|}
\hline Faktörler & Yaş & $\mathbf{N}$ & $\begin{array}{c}\text { Ortalama } \\
\text { Sirası }\end{array}$ & $\begin{array}{l}\text { Kruskal- } \\
\text { Wallis H }\end{array}$ & $\mathbf{p}$ \\
\hline \multirow{4}{*}{$\begin{array}{l}\text { Hatay’ın } \\
\text { Somut } \\
\text { Kültürel } \\
\text { Varlıklarına } \\
\text { İlişkin Tutum } \\
\text { Algıları }\end{array}$} & $16-18$ yaş & 12 & 164,04 & \multirow{4}{*}{5,825} & \multirow{4}{*}{,120 } \\
\hline & 19-21 yaş & 154 & 162,46 & & \\
\hline & $22-24$ yaş & 129 & 167,41 & & \\
\hline & $\begin{array}{l}25 \text { ve } \\
\text { üzeri yaş }\end{array}$ & 43 & 202,49 & & \\
\hline \multirow{4}{*}{$\begin{array}{l}\text { Somut } \\
\text { Kültürel } \\
\text { Varlıklara } \\
\text { İlişkin Genel } \\
\text { Tutum } \\
\text { Algıları }\end{array}$} & $16-18$ yaş & 12 & 204,42 & \multirow{4}{*}{5,360} & \multirow{4}{*}{, 147} \\
\hline & $19-21$ yaş & 154 & 177,92 & & \\
\hline & $22-24$ yaş & 129 & 155,48 & & \\
\hline & $\begin{array}{c}25 \text { ve } \\
\text { üzeri yaş }\end{array}$ & 43 & 171,65 & & \\
\hline
\end{tabular}

Tablo 7'de görüldüğü üzere; katılımcıların Hatay’ın somut kültürel varlıklarına ilişkin tutum algıları anlamlılık düzeyi 0,120, katılımcıların somut kültürel varlıklara ilişkin genel tutum algıları anlamlılık düzeyi 0,147 olarak hesaplanmış ve bu değerler 0,05 'ten büyük olduğundan katılımcıların somut kültürel varlıklara ilişkin tutum algılarını oluşturan faktörler ile yaş değişkeni arasında istatistiki anlamda anlamlı bir farklılık görülmemektedir.
Tablo 8. Öğrencilerin Sınıf Düzeylerine Göre Somut Kültürel Varlıklarına İlişkin Tutum Algılarını Oluşturan Faktörlere Verdikleri Önem Düzeyleri

\begin{tabular}{|c|c|c|c|c|c|}
\hline $\begin{array}{c}\text { Somut Kültürel } \\
\text { Varlıklara İlişkin } \\
\text { Tutum Algılarını } \\
\text { Oluşturan } \\
\text { Faktörler }\end{array}$ & Sinıf & $\mathbf{N}$ & Ort. & $\begin{array}{c}\text { Kruskal } \\
\text {-Wallis } \\
\text { H }\end{array}$ & $\mathbf{p}$ \\
\hline \multirow{4}{*}{$\begin{array}{l}\text { Hatay’ın Somut } \\
\text { Kültürel } \\
\text { Varlıklarına İlişskin } \\
\text { Tutum Algıları }\end{array}$} & 1.Sinıf & 60 & 135,88 & \multirow{4}{*}{10,847} & \multirow{4}{*}{$\begin{array}{l}, 01 \\
3^{*}\end{array}$} \\
\hline & 2.Sinif & 114 & 173,71 & & \\
\hline & 3.Sinıf & 43 & 160,92 & & \\
\hline & 4.Sinıf & 121 & 185,25 & & \\
\hline \multirow{4}{*}{$\begin{array}{l}\text { Somut Kültürel } \\
\text { Varlıklara İlişsin } \\
\text { Genel Tutum } \\
\text { Algıları }\end{array}$} & 1.Sinif & 60 & 164,43 & \multirow{4}{*}{3,308} & \multirow{4}{*}{$\begin{array}{c}34 \\
7\end{array}$} \\
\hline & 2.Sinif & 114 & 182,32 & & \\
\hline & 3.Sinif & 43 & 169,70 & & \\
\hline & 4.Sinif & 121 & 159,86 & & \\
\hline
\end{tabular}

Tablo 8'de görüldügüü üzere; katılımcıların Hatay'ın somut kültürel varlıklarına ilişkin tutum algıları anlamlılık düzeyi 0,013 , olarak hesaplanmış ve bu değer 0,05 'ten küçük olduğundan katılımcıların Hatay'ın somut kültürel varlıklarına ilişkin tutum algıları ile sınıf değişkeni arasında istatistiki anlamda anlamlı bir farklılık olduğu görülmektedir. 4. Sınıfta eğitim gören katılımcıların alg1 düzeylerinin diğer sınıf düzeylerinde eğitim gören katılımcılara oranla daha yüksek olduğu görülmektedir. Katılımcıların somut kültürel varlıklara ilişkin genel tutum algıları anlamlılık düzeyi 0,347 olarak hesaplanmış ve bu değerler 0,05 'ten büyük olduğundan katılımcıların somut kültürel varlıklara ilişkin tutum algılarını oluşturan faktörler ile sınıf düzeyleri değişkeni arasında istatistiki anlamda anlamlı bir farklılık görülmemektedir.

Tablo 9. Öğrencilerin Aylık Gelirlerine Göre Somut Kültürel Varlıklarına İlişkin Tutum Algılarını Oluşturan Faktörlere Verdikleri Önem Düzeyleri

\begin{tabular}{|c|c|c|c|c|c|}
\hline $\begin{array}{l}\text { Somut } \\
\text { Kültürel } \\
\text { Varlıklara } \\
\text { İlişkin Tutum } \\
\text { Algılarını } \\
\text { Oluşturan } \\
\text { Faktörler } \\
\end{array}$ & Aylık Gelir & $\mathbf{N}$ & Ort. & $\begin{array}{l}\text { Kruskal- } \\
\text { Wallis H }\end{array}$ & $\mathbf{p}$ \\
\hline \multirow{5}{*}{$\begin{array}{l}\text { Hatay'ın Somut } \\
\text { Kültürel } \\
\text { Varlıklarına } \\
\text { İlişkin Tutum } \\
\text { Algıları }\end{array}$} & $0-250 \mathrm{TL}$ & 40 & 161,00 & \multirow{5}{*}{1,578} & \multirow{5}{*}{, 813} \\
\hline & $251-500 \mathrm{TL}$ & 110 & 178,65 & & \\
\hline & $501-750 \mathrm{TL}$ & 71 & 163,80 & & \\
\hline & $751-1000 \mathrm{TL}$ & 62 & 167,27 & & \\
\hline & $\begin{array}{l}1001 \text { TL ve } \\
\text { üzeri }\end{array}$ & 55 & 167,26 & & \\
\hline \multirow{5}{*}{$\begin{array}{l}\text { Somut Kültürel } \\
\text { Varlıklara } \\
\text { İlişkin Genel } \\
\text { Tutum Algıları }\end{array}$} & $0-250 \mathrm{TL}$ & 40 & 188,96 & \multirow{5}{*}{2,693} & \multirow{5}{*}{,610 } \\
\hline & $251-500 \mathrm{TL}$ & 110 & 170,73 & & \\
\hline & $501-750 \mathrm{TL}$ & 71 & 160,12 & & \\
\hline & $751-1000 \mathrm{TL}$ & 62 & 172,60 & & \\
\hline & $\begin{array}{l}1001 \text { TL ve } \\
\text { üzeri }\end{array}$ & 55 & 161,50 & & \\
\hline
\end{tabular}

Tablo 9'da görüldüğü üzere; katılımcıların Hatay'ın somut kültürel varlıklarına ilişkin tutum algıları anlamlılık düzeyi 0,813, katılımcıların somut kültürel varlıklara ilişkin genel tutum algıları anlamlılık düzeyi 0,610 olarak hesaplanmış ve bu değerler 0,05 'ten büyük olduğundan katılımcıların somut kültürel varlıklara ilişkin tutum algılarını oluşturan faktörler ile aylık gelir değişkeni arasında istatistiki anlamda anlamlı bir farklılık görülmemektedir. 
Tablo 10. Öğrencilerin İkamet Yerlerine Göre Somut Kültürel Varlıklarına İlişkin Tutum Algılarını Oluşturan Faktörlere Verdikleri Önem Düzeyleri

\begin{tabular}{|c|c|c|c|c|c|}
\hline $\begin{array}{l}\text { Somut } \\
\text { Kültürel } \\
\text { Varlıklara } \\
\text { İlişkin Tutum } \\
\text { Algılarını } \\
\text { Oluşturan } \\
\text { Faktörler }\end{array}$ & $\begin{array}{l}\text { İkamet } \\
\text { Yeri }\end{array}$ & $\mathbf{N}$ & Ort. & $\begin{array}{l}\text { Kruskal- } \\
\text { Wallis H }\end{array}$ & $\mathbf{p}$ \\
\hline \multirow{4}{*}{$\begin{array}{l}\text { Hatay’ın Somut } \\
\text { Kültürel } \\
\text { Varlıklarına } \\
\text { İlişkin Tutum } \\
\text { Algıları }\end{array}$} & Aile yan 1 & 55 & 180,80 & \multirow{4}{*}{1,331} & \multirow{4}{*}{0,722} \\
\hline & Öğrenci evi & 160 & 170,18 & & \\
\hline & $\begin{array}{l}\text { Devlet } \\
\text { yurdu }\end{array}$ & 69 & 166,33 & & \\
\hline & Özel Yurt & 54 & 160,02 & & \\
\hline \multirow{4}{*}{$\begin{array}{l}\text { Somut Kültürel } \\
\text { Varlıklara } \\
\text { İlişkin Genel } \\
\text { Tutum Algıları }\end{array}$} & Aile yanı & 55 & 166,10 & \multirow{4}{*}{2,209} & \multirow{4}{*}{, 530} \\
\hline & Öğrenci evi & 160 & 164,59 & & \\
\hline & $\begin{array}{l}\text { Devlet } \\
\text { yurdu }\end{array}$ & 69 & 184,92 & & \\
\hline & Özel Yurt & 54 & 167,81 & & \\
\hline
\end{tabular}

Tablo 10’da görüldüğü üzere; katılımcıların Hatay’ın somut kültürel varlıklarına ilişkin tutum algıları anlamlılık düzeyi 0,722 , katılımcıların somut kültürel varlıklara ilişkin genel tutum algıları anlamlılık düzeyi 0,530 olarak hesaplanmış ve bu değerler 0,05 'ten büyük olduğundan katılımcıların somut kültürel varlıklara ilişkin tutum algılarını oluşturan faktörler ile ikamet yerleri değişkeni arasında istatistiki anlamda anlamlı bir farklılık görülmemektedir.

Tablo 11. Öğrencilerin Aile İkamet Yerlerine Göre Somut Kültürel Varlıklarına İlişkin Tutum Algılarını Oluşturan Faktörlere Verdikleri Önem Düzeyleri

\begin{tabular}{|c|c|c|c|c|c|}
\hline $\begin{array}{l}\text { Somut Kültürel } \\
\text { Varlıklara İlişkin } \\
\text { Tutum Algılarını } \\
\text { Oluşturan } \\
\text { Faktörler }\end{array}$ & $\begin{array}{l}\text { Aile } \\
\text { Íkamet } \\
\text { Yeri }\end{array}$ & $\mathbf{N}$ & Ort. & $\begin{array}{l}\text { Kruskal- } \\
\text { Wallis H }\end{array}$ & $\mathbf{p}$ \\
\hline \multirow{3}{*}{$\begin{array}{l}\text { Hatay'ın Somut } \\
\text { Kültürel } \\
\text { Varlıklarına İlişkin } \\
\text { Tutum Algıları }\end{array}$} & $\dot{\mathrm{I} l}$ & 148 & 160,95 & \multirow{3}{*}{2,040} & \multirow{3}{*}{,361 } \\
\hline & İlçe & 137 & 176,71 & & \\
\hline & Köy & 53 & 174,73 & & \\
\hline \multirow{3}{*}{$\begin{array}{l}\text { Somut Kültürel } \\
\text { Varlıklara İlişkin } \\
\text { Genel Tutum } \\
\text { Algıları }\end{array}$} & İl & 148 & 168,12 & \multirow{3}{*}{0,173} & \multirow{3}{*}{,917 } \\
\hline & İlçe & 137 & 172,10 & & \\
\hline & Köy & 53 & 166,61 & & \\
\hline
\end{tabular}

Tablo 11 'de görüldüğü üzere; katılımcıların Hatay'ın somut kültürel varlıklarına ilişkin tutum algıları anlamlılık düzeyi 0,361, katılımcıların somut kültürel varlıklara ilişkin genel tutum algıları anlamlılık düzeyi 0,917 olarak hesaplanmış ve bu değerler 0,05 'ten büyük olduğundan katılımcıların somut kültürel varlıklara ilişkin tutum algılarını oluşturan faktörler ile aile ikamet yerleri değişkeni arasında istatistiki anlamda anlamlı bir farklılık görülmemektedir.

\section{Sonuç ve Öneriler}

Yapılan araştırmada İskenderun Teknik Üniversitesi Turizm İşletmeciliği ve Otelcilik Yüksekokulu lisans öğrencilerinin somut kültürel miraslar ve Hatay'da bulunan somut kültürel miraslar hakkındaki algı düzeylerini ölçmek ve ölçülen bu değerler için farkındalık oluşturmak amaçlanmaktadır. Katılımcıların alg1 düzeylerini belirleyen faktörler ile demografik değişkenler arasındaki ilişkiyi ölçmek için analizler gerçekleştirilmiştir.

Araştırmaya katılan öğrencilerin demografik özellikleri incelendiğinde; literatür ve örneklem özellikleriyle örtüşür şekilde çoğunluğun erkek öğrencilerden oluştuğu, 19-21 yaş grubu katılımcıların ağırlıkta olduğu ve gelir düzeylerinin 251-
500 TL aralığında olduğu, tespit edilmiştir (Demirbulat vd., 2015;). Katılımcıların seyahat işletmeciliği bölümüne göre turizm ve otel işletmeciliği bölümünü $\% 71,0$ oranında daha fazla tercih ettiği görülmektedir. Bunun sebebinin ise turizm ve otel işletmeciliği bölümünün çalışma alanlarının seyahat işletmeciliği bölümü çalışma alanlarına oranla daha fazla olduğunun düşünülmesinden kaynaklandığ1 söylenebilir. Öğrencilerin \%71,9'unun Hatay iline yalnızca eğitim amaçlı geldikleri tespit edilmiştir. Buna sebep olarak ise Hatay ilinin Suriye sınırında yer alması ve bunun aileler açısından güvenlik endişesi uyarması olduğu söylenebilir. Öğrencilere yöneltilen Hatay'da gezerken tarihi bir bina gördüğünüzde ne hissediyorsunuz sorusuna \%52,4'ünün merak yanıtını verdiği görülmüştür. Ayrıca öğrencilerin \%4,23'ünün Hatay’ın somut kültürel varlıkları arasından Hatay'ı simgeleyen en önemli kültür varlığının Hatay Arkeoloji Müzesi olduğunu belirtmişlerdir.

Katılımcıların algılarını ölçmek için literatürdeki ilgili çalışmadan yararlanılarak 'Hatay'ın somut kültürel varlıklarına ilişkin tutum algıları' , 'somut kültürel varlıklara ilişkin genel tutum algıları' şeklinde iki faktör kullanılmıştır. Belirlenen bu faktörler ile demografik değişkenler arasındaki ilişkiyi ölmek için Mann Whitney U ve Kruskal Wallis H testleri uygulanmıştır.

Hatay'ın somut kültürel varlıklarına ilişkin tutum algıları ile memleket yeri değişkeni arasında istatistiki anlamda anlamlı bir farklılık olduğu görülmektedir. Hatay'lı katılımcıların alg1 düzeylerinin Hatay'lı olmayan katılımcılara oranla daha yüksek olduğu görülmektedir. Bu sonuca bakılarak yerli halkı temsil eden öğrencilerin kendi kültürlerini daha iyi tanıdığg 1 ve gerekli kurum ve kuruluşlar tarafindan Hatay ilinin kültürel miraslarına yönelik gerekli tanıtım çalışmalarının yeterli yapılmadığı veya öğrencilerin çeşitli kısıtlar doğrultusunda kültürel aktivitelere katılım gösteremedikleri söylenebilir. Hatay'ın somut kültürel varlıklarına ilişkin tutum algıları ile sınıf değişkeni arasında istatistiki anlamda anlamlı bir farklılık olduğu görülmektedir. 4. Sınıfta eğitim gören katılımcıların alg1 düzeylerinin alt sınıf düzeylerinde eğitim gören katılımcılara oranla daha yüksek olduğu görülmektedir. $\mathrm{Bu}$ sonuca bakılarak son sınıfta öğrenim gören öğrencilerin bilgi birikim düzeylerinin ve son sınıfa gelene kadar katılmış oldukları kültür turizmi aktivitelerinin öğrencilerin algıları üzerinde etkili olduğu söylenebilir.

Hatay'ın somut kültürel varlıklarının öğrenciler tarafından nasıl algılandığının araştırıldığı bu çalışma belirli kısıtlar dolayısıyla İskenderun Teknik Üniversitesi'nde öğrenim gören turizm öğrencilerine uygulanmıştır. Araştırmanın, bundan sonra yapılacak olan çalışmalara öncülük etmesi hedeflenmektedir. $\mathrm{Bu}$ çalışmanın belirli aralıklarla tekrarlanması halinde elde edilen sonuçların, hem yerli halkın ve öğrencilerin gelişimine hem de Hatay turizminin gelişimine ve bölgesel tanıtıma yön verilebilmesi öngörülmektedir. Bununla birlikte gelecekte yapılacak olan çalışmalarda evrenin daha geniş tutularak, örneklem olarak tesadüfi örneklem yöntemi ile daha çeşitli sonuç ve görüşlere ulaşıllabileceği öngörülmektedir. 


\section{Kaynakça}

(Erişim

25.10.2018)

http://www.tdk.gov.tr/index.php?option=com_gts\&kel ime $=\mathrm{K} \% \mathrm{C} 3 \% 9 \mathrm{CLT} \% \mathrm{C} 3 \% 9 \mathrm{CR}$

(Erişim Tarihi: 01.02.2018), https://www.coe.int/en/web/portal/home

(Erişim:

11.12.2018)

http://teftis.kulturturizm.gov.tr/TR,14269/dunya-

kulturel-ve-dogal-mirasin-korunmasi-sozlesmesi.html

(Erişim: 15.11.2018), http://www.iste.edu.tr/

(Erişim:12.11.2018), Erisim:15.12.2017

(Erişim:18.12.2018), http://www.kulturvarliklari.gov.tr/TR199568/2018-yili-duyurulari.html

Aas, C., Ladkg்n, A. \& Fletcher, J. (2005). Stakeholder Collaboration and Heritage Management. Annals of Tourism Research, 32(1), 28-48.

Ablak, S., Dikmenli, Y. Ve Çetin, T. (2014). "Üniversite Öğrencilerinin Kırşehir'in Tarihi Ve Kültürel Turizm Değerlerine Yönelik Farkındalıkları”, Uşak Üniversitesi Sosyal Bilimler Dergisi, 7 (2), 171-186.

Ahunbay, Z. (2007). Tarihi Çevre Koruma ve Restorasyon. İstanbul: YEM.

Akipek, S. (2001). Dünya Kültürel Ve Doğal Mirasının Korunmasına Dair Sözleşmenin Değerlendirilmesi. $A \ddot{U}$ Hukuk Fakültesi Dergisi, 50(4), 13-40.

Aliağaoğlu, A. (2004). Sosyo-Kültürel Miras Turizmi ve Türkiye'den Örnekler. Ankara Üniversitesi Türkiye Coğrafyası Araştırma ve Uygulama Merkezi Coğrafi Bilimler Dergisi, 2 (2), 54-64.

Altunişik, R., Coşkun, R., Bayraktaroğlu, S., \& Yildirim, E. (2007). Sosyal bilimlerde araştırma yöntemleri. Sakarya: Sakarya Yayıncılık.

Alzahran1, D., A. (2013). The Adoption of a Standard Definition of Cultural Heritage. International Journal Of Social Science And Humanity, 3(1), 9-12.

Can M. (2009). Kültürel Miras Ve Müzecilik. Kültür Ve Turizm Bakanlı̆gl.

Demirbulat, Ö. G., Saatcı, G. \& Avcıkurt, C. (2015). Bursa'nın Somut Kültürel Varlıklarına Yönelik Öğrencilerin Algılar1: Harmancık MYO Örneği. Gümüshane Üniversitesi Sosyal Bilimler Enstitüsü Elektronik Dergisi, 6 (12).

Demirbulat, Ö. G., Saatc1, G. Ve Avcıkurt, C. (2015). "Bursa'nın Somut Kültürel Varlıklarına Yönelik Öğrencilerin Algıları: Harmancık MYO Örneği””. Gümüshane University Electronic Journal Of The Institute Of Social Science/Gümüshane Üniversitesi Sosyal Bilimler Enstitüsü Elektronik Dergisi, 6 (12), 62-86.

Doğaner, S. (2001). Türkiye Turizm Coğrafyası. İstanbul: Çantay.

Giritlioğlu, İ., Armutcu, B., \& Düzgün, M. (2016). Geleneksel Gaziantep Mutfağının Kuşaklararası Bilinirliğine
Yönelik Bir Araştırma. Mehmet Akif Ersoy Üniversitesi Sosyal Bilimler Enstitüsü Dergisi, 8(17), 126-138.

Golzardi, F., Sarvaramini, S., \& Sarvaramini, M. (2012). Residents Attitudes Towards Tourism Development: A Case Study Of Niasar, Iran. Research Journal Of Applied Sciences, Engineering And Technology, 4(8), 863-868.

Gökçe, Ö. G. F., Cihangir, Ö. G. İ. S., Sunar, B. U. H., \& Summak, M. E. Kreatif Turizm Ve Hatay'da Var Olan Potansiyeli Üzerine Bir Araştırma. Socıal Scıences Studies Journal. 3(7), 1470-1479

Günal, V., Alaeddinoğlu, F., \& Şahinalp, M. S. (2009). Türkiye’ye Yönelik Kültürel Turizm Turları Ve Başlıca Güzergâhlar. Gaziantep University Journal Of Social Sciences, 8(1), 275-298.

Hacıŏlu, Necdet \& Avcıkurt, Cevdet (2008). Turistik Ürün Çeşitlendirmesi. Ankara: Nobel.

Hughes, H. L. (2002). Culture and tourism: a framework for further analysis. Managing Leisure, 7(3), 164-175.

Karaca, Ş., Akkuş, G., Şahbudak, E. \& Işkın, M. (2017). "Kültürel Miras Farkındalığı: Cumhuriyet Üniversitesi Öğrencilerine Yönelik Bir Uygulama Çalışması. Akademik Araştırmalar ve Çalışmalar Dergisi, 9 (16), 86-100.

Kiper, T. (2006). Safranbolu Yörük Köyü Peyzaj Potansiyelinin Kursal Turizm Açısindan Değerlendirilmesi. Doktora Tezi. Ankara: Ankara Üniversitesi.

Kozak, N., Tören, E., \& Demiral, G. N. (2012). Eskişehir'in Kültürel Miras Varlıklarının Korunmasında Kamu Kurumlarının Rolü. Aksaray Üniversitesi İktisadi İdari Bilimler Fakültesi Dergisi, 4(2), 69-88.

Kurgun, H., \& Yumuk, Y. (2013). Yöresel El Sanatlarının Kültürel Turizmin Gelișimindeki Rolü: Görece (Boncukköy) ve Nazarköy Örnekleri. Uluslararası Sosyal Ve Ekonomik Bilimler Dergisi, (1), 27-32.

Kutlu, M. M. (2009). Somut Olmayan Kültürel Mirasın Korunmasında Eğitime Yönelik İlk Adım: Halk Kültürü Dersi. Milli Folklor, 21(82), 1318.Küçükaltan, D., (2011). Kültürel Miras Yönetimi. İçinde: Mustafa Çakır (Ed.), Destinasyon (s. 50-72). Eskişehir: Eskişehir Anadolu Üniversitesi Yayınları.

Külcü, Ö., T. (2015). Kültürel Miras Kavramının Eğitim Açısından Önemi. Akademia Disiplinlerarası Bilimsel Araştırmalar Dergisi, 1(1), 27-32.

McKercher, B., Ho, P. S., \& Du Cros, H. (2005). Relationship between tourism and cultural heritage management: evidence from Hong Kong. Tourism management, 26(4), 539-548.

Mckercher, B., Ho, P.S. \& Cros, H. (2005). Relationship Between Tourism And Cultural Heritage Management: Evidence From Hong Kong. Tourism Management, 26(4), 539-548.

Özdamar, K. (2011). Paket Programlar İle Istatistiksel Veri Analizi-1. Eskişehir: Kaan Kitabevi. 
Özdemir, M. Z. D. (2005). Türkiye'de Kültürel Mirasın Korunmasına Kısa Bir Bakış. Planlama, TMMOB Şehir Plancıları Odası Yayını, 31, 20-25.

Özdemir, Ü. (2011). Safranbolu'nun Kültürel Miras Kaynakları Ve Korunması. Doğu Coğrafya Dergisi, 16(26),129-141.

Selanik Ay, T., \& Kurtdede Fidan, N. (2013). Öğretmen Adaylarının" Kültürel Miras" Kavramına İlişkin Metaforlar1. Electronic Turkish Studies, 8(12), 1135 1152.

Shackley, M. (1997). Saving Cultural Information:The Potential Role of Digital Databases In Developing

Teo, P. ve Huang, S. (1995). Tourism and Heritage Conservation in Singapore, Annals of Tourism Research, 22(3), 589-615.

Tosun, C. Ve Bilim, Y. (2004). Hatay'ın Turistik Bir Şehir Olarak Pazarlanması, I. Balıkesir Ulusal Turizm Kongresi, 15-16 Nisan 2004, 269-288.

Ural, A. \& Kılıç, İ. (2013). Bilimsel Araştırma Süreci Ve SPSS Ile Veri Analizi. Ankara: Detay Yayıncılık.

Usta, N. (2012). İnanç Turizminden Kültür Turizmine: Midilli Adası'nın Agiasos Dağ Köyü Örneği. KMÜ Sosyal ve Ekonomik Araştırmalar Dergisi, 14(22), 163-168.

Uygur, S. M. \& Baykan, E. (2007). Kültür Turizmi ve Turizmin Kültürel Varlıklar Üzerindeki Etkileri. Ticaret ve Turizm Ĕ̈itim Fakültesi Dergisi, 2 (1), 3049.
Cultural Tourism. Journal of Sustainable Tourism, 5 (3), 244-249.

Shankar, B. \& Swamy, C. (2013). Creating Awareness For Heritage Conservation in the City of Mysore. Issues and Policies. International Journal of Modern Engineering Research, 3(2), 698-703.

Tankut, G. (2005). Doğal Ve Tarihi Çevrenin Korunması: Sorunlar Ve Olası Çözümler. Planlama, TMMOB Türliye Şehir Plancıları Odası Yayını, 31, 9-12.

Taylor, K. (2007). Cultural Heritage Management: A Possible Role For Charters and Principles in Asia. International Journal of Heritage Studies, 10(5), 417-433.

Üsküdar, M. Çakır \& Temizkan. S, P. (2014). Yerli Turistlerin Eskişehir'in Kültür Turizmine İlişkin Algıları. Journal of Tourism and Gastronomy Studies, 2 (2), 67-76.

Üsküdar, Ş., Çakır, M., \& Temizkan, S. P. (2014). Yerli turistlerin Eskişehir'in Kültür Turizmine İlişkin Algilar1. Journal of Tourism and Gastronomy Studies, 2(2), 67-76.4

Vecco, M. (2010). A Definition of Cultural Heritage: From The Tangible To The Intangible. Journal of Cultural Heritage, 11(1), 321-324.

Wang, S., Fu, Y. Y., Cecil, A. \& Avgoustgis, S. H. (2006). Residents' Perceptions of Cultural Tourism and Quality of Life- A Longitudinal Approach. Tourism Today, 6, 47-61. 